\title{
The influence of the grain-size, mineralogical and geochemical composition on the Verdesca landslide
}

\author{
V. Summa ${ }^{1}$, S. Margiotta ${ }^{1,2}$, R. Colaiacovo ${ }^{1}$, and M. L. Giannossi ${ }^{1}$ \\ ${ }^{1}$ Laboratory of Environmental \& Medical Geology, CNR IMAA, C. da S. Loya, 85050, Tito Scalo, Potenza, Italy \\ ${ }^{2}$ Osservatorio Ambientale Val d'Agri, Via Vittorio Emanuele II, 3, 85052, Marsico Nuovo, Potenza, Italy \\ Correspondence to: V. Summa (vito.summa@imaa.cnr.it)
}

Received: 29 May 2014 - Published in Nat. Hazards Earth Syst. Sci. Discuss.: 6 August 2014

Revised: - - Accepted: 9 December 2014 - Published: 20 January 2015

\begin{abstract}
Silty sands and clayey silts taken from a landslide in the Agri Valley have been analysed in order to study the role of sediment composition in the slope stability and the development of a slip zone. A geognostic hole was used to collect samples and monitor movements. A slip zone at a depth of about $14 \mathrm{~m}$ was identified. Compositional and physical-mechanical characterisation of samples was carried out. Some compositional characters, such as a $32-2 \mu \mathrm{m}$ grain-size fraction, clay mineral content, cation exchange capacity and total nitrogen, increase in the slip zone. Some correlations have been found between geotechnical properties (residual shear strength and residual friction angle) and the same compositional characters, which can therefore be considered possible factors influencing slope stability.
\end{abstract}

\section{Introduction}

Landslides often occur in anthropic environments and in urbanised and industrial areas, and can cause serious socioeconomic damage, including the loss of human life. Geomorphological studies of landslides are not sufficient to understand the complex dynamics influencing the mechanisms of movement, as the role of the compositional characteristics of sediments and waters circulating represents a key problem, especially in contexts where fine sediments prevail.

Several studies have indeed shown that there could be some relation between physical-mechanical properties of sediments and their granulometrical, chemical and mineralogical characteristics, as well as with the composition of circulating waters (e.g. Torrance, 1999; Sridharan, 2001). The behaviour of landslide clayey sediments is the response to their physical and mechanical properties, depending on water-clay interaction, clay fabric and clay mineral content, both quantitatively and qualitatively (Di Maio, 1996a, b; Martinez-Nistal et al., 1999; Cafaro and Cotecchia, 2001; Cotecchia, 2003; Loroueil and Hight, 2003; Bogaard et al., 2007; Summa et al., 2007, 2008, 2010). For this reason, in the last few years, there has been an increasing scientific interest in the physical, chemical and mineralogical characteristics of sediments with respect to slope stability.

Our attention has been focused on a pilot area in the Agri Valley, an intermountain basin in the southern Apennines (Basilicata, Italy), often affected by land degradation processes (especially in the form of gullies and biancane) and mass gravitational movements involving mainly fine sediments with clay components. Sediments and waters circulating in a landslide near the village of Montemurro were characterised in order to study the role of sediment composition in the slope stability and to identify possible geochemical and mineralogical hazard factors. The slope involved in the investigated landslide shows a very complex geological and geomorphological framework, complicated by a very strong Quaternary morphodynamic. For this reason, the causes of movement are not yet fully understood, despite numerous studies in the last century. In the last few years, a slow activity is evident, causing obvious structural damage to infrastructure and buildings, and the interest in this landslide has increased.

\section{Geological and geomorphological landslide context}

The studied landslide is situated in Verdesca, near the village of Montemurro, on the left orographic side of the Agri River. 

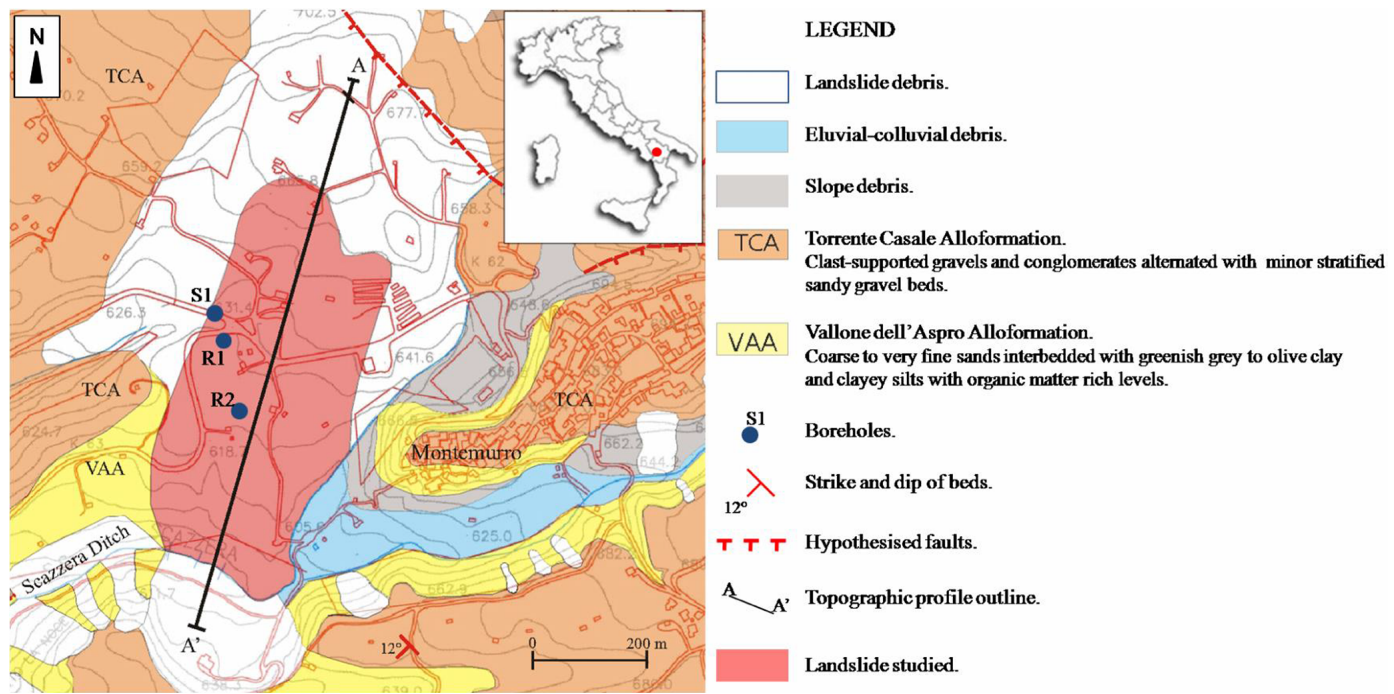

Figure 1. Sketch geological map of the investigated area.

The landslide is occurring to the far west of the village, and is on a semi-urbanised slope, which includes several infrastructures and buildings (Fig. 1).

In the investigated area, a continental clastic Quaternary sequence crops out; it is mainly represented by deposits of alluvial fan, alluvial plain and lacustrine environments, corresponding to the upper and middle intervals of the Complesso Val d'Agri (Di Niro et al., 1992) and to the Torrente Casale and Vallone dell'Aspro alloformations (Zembo, 2010). The Torrente Casale alloformation is represented by massive coarse deposits such as matrix-to-clast-supported gravels and conglomerates, alternating with sandy gravels and gravelly sands. The Vallone dell'Aspro alloformation is characterised by coarse to fine sands and stratigraphically lower greenish to grey silty clays and clayey silts, interbedded with organicrich and peaty horizons (Zembo, 2010; Gueguen et al., 2015). These deposits rest on an angular unconformity truncating the Miocene bedrock, consisting of sandstones from the Gorgoglione Flysch, which outcrops mainly with its peliticarenaceous component (Boenzi et al., 1968; Boenzi and Ciaranfi, 1970; Critelli and Loiacono, 1988; Mutti and Normark, 1987; Butler and Tavarnelli, 2006; Gueguen et al., 2015). The area is affected by extensional faults of the Val d'Agri fault system (Cello, 2000; Cello et al., 2000a, b, 2003; Bucci et al., 2012, 2014).

As indicated by Gueguen et al. (2015), the landslide is complex, with a rotational component in the upper sector evolving into a translational slide in the lower part. Minor scarps, terrace-like features and counter-slopes were detected, and further superficial movements were identified due to the continuous erosion of a ditch flowing at the foot of the landslide.

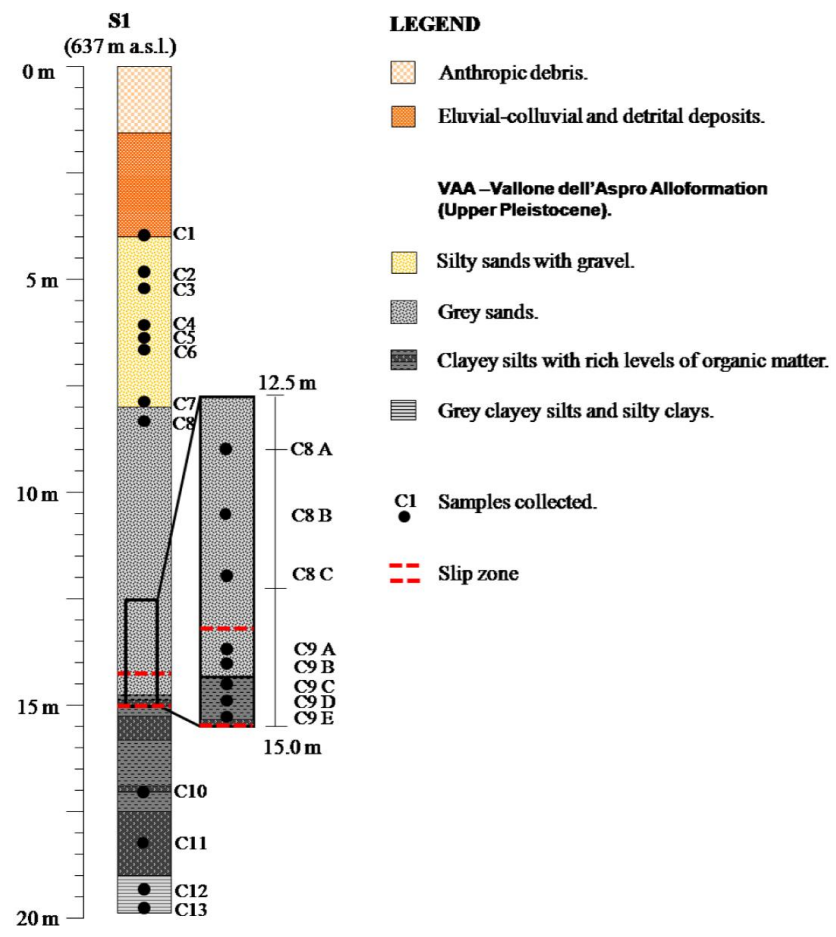

Figure 2. Stratigraphic sequence of the S1 borehole with the positions of the investigated samples.

\section{Materials and methods}

A geognostic hole equipped with an inclinometer tube (S1, Figs. 1 and 2) was used to reconstruct the stratigraphic sequence of the deposits involved in the landslide and to collect the sediment samples submitted for physicalmechanical characterisation (Atterberg's limits and residual shear strength parameters) and compositional analyses (grain 


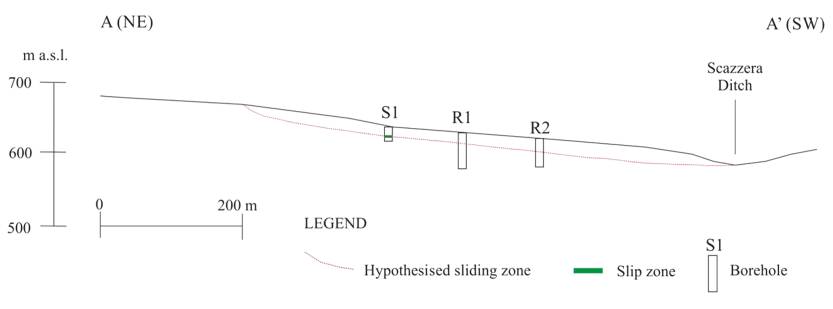

Figure 3. Topographic profile (trace $\mathrm{A}-\mathrm{A}^{\prime}$ in Fig. 1) with the hypothesised trend of the sliding zone.

size, mineralogy and geochemistry). The samples were collected after considering several lithologies found in the geognostic hole and the position of the slip zone. Twenty samples were collected, with a higher concentration of samples taken near and from the slip zone identified (between 12.5 and $15.0 \mathrm{~m}$ ), as shown in Fig. 2. It was not possible to carry out some compositional analyses in some samples, due to insufficient amounts available.

Grain-size analyses were carried out using wet sieving and fractional sedimentation following Stokes' law. Pretreatments, using a deflocculant (a few drops of $\mathrm{NH}_{3}$ ), were performed on some samples with a high content of colloidal particles.

Mineralogical analyses were carried out by means of a Rigaku Rint 2200 X-ray powder diffractometer (XRD), using $\mathrm{Cu}$ Ka radiation, a secondary monochromator and a sample spinner. Bulk rocks were mounted in a very thin sample holder, whereas the $<2 \mu \mathrm{m}$ fraction was analysed using oriented specimens after ethylene glycol solvation (overnight at $60^{\circ} \mathrm{C}$ ) and heating at $375^{\circ} \mathrm{C}$. The characterisation of mixed-layer clays was accomplished following Moore and Reynolds (1989) and the semi-quantitative estimate follows Biscaye (1965), with slight modifications.

Organic carbon and total nitrogen were determined using CHNS-Leco. Von Bemmelen's factor was used for calculating the organic matter content from organic carbon (Buringh, 1984). The $\mathrm{pH}$ measurements were carried out in accordance with the procedure in Italian law no. 79, 11 May 1992 ("Metodi ufficiali di analisi chimica del suolo").

The sodium adsorption ratio (SAR) was determined on a soil/water suspension prepared by mixing $4 \mathrm{~g}$ of sediment and $40 \mathrm{~mL}$ of distilled water. The suspension was shaken for $12 \mathrm{~h}$, using mechanical shakers, centrifuged and filtered. The supernatant was analysed using inductively coupled plasmaoptical emission spectrometers (ICP-OES), to determine the amount of sodium.

Cation exchange capacity (CEC) and several exchangeable cations, such as magnesium percentage (EMP), calcium percentage (ECP), sodium percentage (ESP) and potassium percentage (EPP), were determined using ICP-OES on samples pretreated with ammonium acetate following the method proposed by Chapman (1965).
In order to characterise samples representative of the slip zone and sediments above and below, a selection of samples was collected and submitted for shear tests. The residual friction angle $\left(\varphi_{\mathrm{r}}\right)$ and residual shear strength $\left(\tau_{\mathrm{r}}\right)$ were determined, by means of direct shear tests in the Casagrande box, by shearing the specimens back and forth at least six times, until a residual constant minimum value of strength was reached. Tests were performed on specimens reconstituted with distilled water.

Liquid limit (WL), plastic limit (WP) and plastic index (PI) were also determined, in accordance with the ASTM rules (2007).

Groundwater sampling was performed on a spring and in a well close to the $\mathrm{S} 1$ borehole, using a stainless steel bailer. The samples were collected in polyethylene bottles and partly acidified with $\mathrm{HNO}_{3}$.

\section{Results}

\subsection{Geognostic survey and stratigraphy}

A detailed stratigraphy of the S1 borehole is shown in Fig. 2. The first $4 \mathrm{~m}$ below ground level were characterised by detrital and eluvial-colluvial deposits with a prevalent sandy component, with a reddish colouring due to important groundwater circulation and strong oxidation processes. From 4 to $8 \mathrm{~m}$, there are yellowish silty sands and gravels with sharp-edged (mainly carbonatic) clasts, from millimetres to centimetres in size. Up to about $14.5 \mathrm{~m}$ below ground level, identical sandy sediments were identified, with a strong depth variability of the clayey component and grey colouring due to a lesser alteration degree than upper deposits. From about 14.5 to $20 \mathrm{~m}$ (bottom hole), grey clayey silts and silty clays were identified, with interbedded blackish and greenish peaty horizons at several stratigraphic depths. Dark nodules and blackish saline concretions were also identified, mainly due to solubilisation-precipitation processes, favoured by groundwater circulation. The sediments described are attributable to the Vallone dell'Aspro alloformation of Zembo (2010).

The break of the inclinometer tube in the $\mathrm{S} 1$ borehole at a depth of $14.3 \mathrm{~m}$ allowed the identification of an active slip zone at that depth, corresponding to the transition from coarser sandy-silty to finer silty-clayey sediments. This transition has a thickness of about $50 \mathrm{~cm}$. The same transition was identified in the stratigraphic sequence of two further geognostic holes (R1 and R2 in Fig. 1) reported in Gueguen et al. (2015). Based on the depth of the lithologic transition in all three boreholes, the hypothesised trend of the sliding zone is reported in the profile shown in Fig. 3. It is not possible to exclude further slip zones at greater depths under the superficial break. 
Table 1. Grain-size composition and geotechnical characters of analysed samples (WL = liquid limit; WP $=$ plastic limit; $\mathrm{PI}=$ plastic index; $\varphi_{\mathrm{r}}=$ residual friction angle; $\tau_{\mathrm{r}}=$ residual shear strength). Slip zone samples are reported in bold.

\begin{tabular}{lrrrrrrrrrrrrr}
\hline Sample & $\begin{array}{r}\text { Depth } \\
(\mathrm{m})\end{array}$ & $\begin{array}{r}r \\
(\mu \mathrm{m})\end{array}$ & $\begin{array}{r}63-32 \\
(\mu \mathrm{m})\end{array}$ & $\begin{array}{r}32-16 \\
(\mu \mathrm{m})\end{array}$ & $\begin{array}{r}16-8 \\
(\mu \mathrm{m})\end{array}$ & $\begin{array}{r}8-4 \\
(\mu \mathrm{m})\end{array}$ & $\begin{array}{r}4-2 \\
(\mu \mathrm{m})\end{array}$ & $\begin{array}{r}<2 \\
(\mu \mathrm{m})\end{array}$ & $\begin{array}{r}\text { WL } \\
(\%)\end{array}$ & $\begin{array}{r}\text { WP } \\
(\%)\end{array}$ & $\begin{array}{r}\text { PI } \\
(\%)\end{array}$ & $\begin{array}{r}\phi_{\mathrm{r}} \\
\left({ }^{\circ}\right)\end{array}$ & $\begin{array}{r}\tau_{\mathrm{r}} \\
(\mathrm{kPa})\end{array}$ \\
\hline C1 & 4.0 & 49 & 7 & 6 & 8 & 9 & 8 & 13 & 41 & 20 & 21 & & \\
C2 & 4.9 & 62 & 13 & 6 & 4 & 7 & 2 & 6 & 34 & 23 & 11 & & \\
C3 & 5.3 & 70 & 7 & 4 & 4 & 4 & 4 & 7 & 29 & 22 & 7 & & \\
C4 & 6.2 & 58 & 16 & 5 & 5 & 4 & 3 & 9 & 28 & 23 & 5 & & \\
C5 & 6.4 & 60 & 8 & 6 & 7 & 6 & 6 & 7 & 40 & 22 & 18 & & \\
C6 & 6.7 & 53 & 10 & 8 & 7 & 7 & 8 & 7 & 35 & 23 & 12 & & \\
C7 & 8.0 & 77 & 6 & 3 & 3 & 3 & 2 & 6 & 22 & 17 & 5 & & \\
C8 & 8.4 & 71 & 6 & 4 & 5 & 5 & 3 & 6 & 30 & 17 & 13 & & \\
C8 A & 13.0 & 72 & 8 & 5 & 4 & 4 & 2 & 5 & 24 & 18 & 6 & 36 & 227 \\
C8 B & 13.5 & 79 & 7 & 3 & 3 & 3 & 2 & 3 & 19 & 14 & 5 & & \\
C8 C & 13.9 & 65 & 9 & 6 & 5 & 5 & 3 & 7 & 25 & 16 & 9 & & \\
C9 A & $\mathbf{1 4 . 5}$ & $\mathbf{8 1}$ & $\mathbf{7}$ & $\mathbf{3}$ & $\mathbf{3}$ & $\mathbf{2}$ & $\mathbf{2}$ & $\mathbf{2}$ & $\mathbf{2 3}$ & $\mathbf{1 6}$ & $\mathbf{7}$ & $\mathbf{3 6}$ & $\mathbf{2 5 3}$ \\
C9 B & $\mathbf{1 4 . 6}$ & $\mathbf{7 1}$ & $\mathbf{1 0}$ & $\mathbf{5}$ & $\mathbf{4}$ & $\mathbf{4}$ & $\mathbf{3}$ & $\mathbf{3}$ & & & & & \\
C9 C & $\mathbf{1 4 . 7}$ & $\mathbf{1 3}$ & $\mathbf{1 1}$ & $\mathbf{1 7}$ & $\mathbf{1 5}$ & $\mathbf{8}$ & $\mathbf{8}$ & $\mathbf{2 8}$ & $\mathbf{5 5}$ & $\mathbf{3 2}$ & $\mathbf{2 3}$ & & \\
C9 D & $\mathbf{1 4 . 8}$ & & & & & & & & & & & $\mathbf{2 0}$ & $\mathbf{1 7 1}$ \\
C9 E & $\mathbf{1 4 . 9}$ & $\mathbf{1 0}$ & $\mathbf{6}$ & $\mathbf{1 5}$ & $\mathbf{1 3}$ & $\mathbf{1 6}$ & $\mathbf{1 1}$ & $\mathbf{2 9}$ & $\mathbf{4 3}$ & $\mathbf{2 5}$ & $\mathbf{1 8}$ & $\mathbf{2 3}$ & $\mathbf{1 2 6}$ \\
C10 & 17.0 & 7 & 7 & 14 & 20 & 20 & 11 & 21 & 67 & 29 & 38 & 12 & 94 \\
C11 & 18.5 & 0 & 0 & 6 & 8 & 17 & 15 & 54 & 87 & 57 & 30 & & \\
C12 & 19.4 & 36 & 17 & 7 & 8 & 10 & 9 & 13 & 40 & 18 & 22 & & \\
C13 & 20.0 & 32 & 18 & 10 & 9 & 10 & 6 & 15 & 27 & 20 & 7 & 31 & 275 \\
$\bar{\chi}$ & & 51 & 9 & 7 & 7 & 8 & 6 & 13 & 37 & 23 & 14 & 26 & 191 \\
$\sigma$ & & 27 & 4 & 4 & 5 & 5 & 4 & 13 & 17 & 10 & 10 & 10 & 72 \\
\hline
\end{tabular}

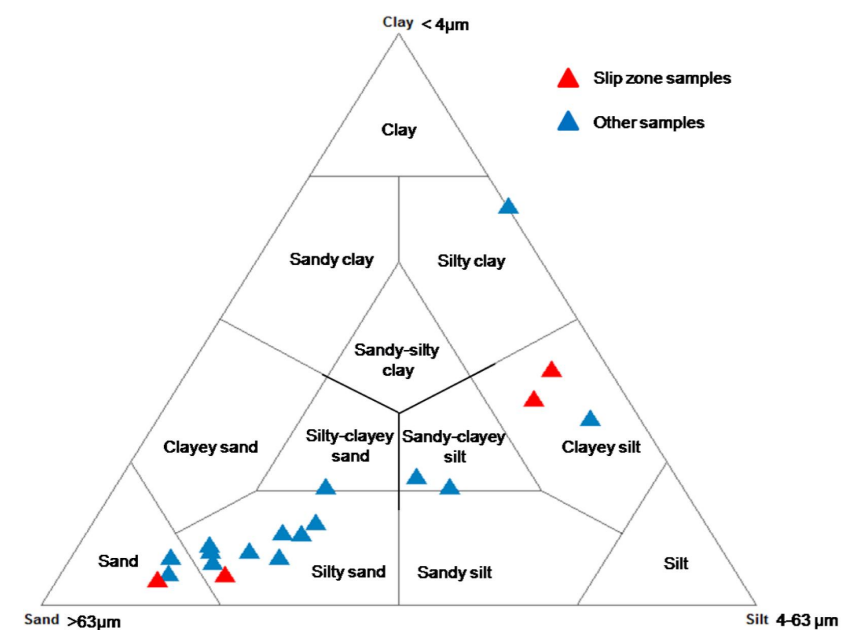

Figure 4. Shepard diagram of the collected samples.

\subsection{Grain-size composition}

The grain-size results are reported in Table 1. According to the Shepard diagram (1954), the samples show a grain-size distribution ranging from sands to clayey silts, with a predominance of silty sands and one silty-clayey sample without a sandy component (Fig. 4). As shown in this diagram, the sediments of the slip zone are sands (C9A), silty sands (C9B) and clayey silts $(\mathrm{C} 9 \mathrm{C}, \mathrm{C} 9 \mathrm{E})$. An increase in the silty (63$2 \mu \mathrm{m})$ and clayey $(<2 \mu \mathrm{m})$ fractions was found at a depth below $14.7 \mathrm{~m}$ (Fig. 5). Particularly, the increase in the silty component is due to the middle-fine $32-2 \mu \mathrm{m}$ fraction, as indicated in Fig. 6.

\subsection{Mineralogical composition}

As reported in Table 2, the sediments are composed mainly of clay minerals and quartz, on average 40 and $36 \%$, respectively. Feldspars $(15 \%)$ and carbonates $(8 \%)$, with calcite $(6 \%) \gg$ dolomite $(2 \%)$, occur in minor amounts.

Traces of hematite and gypsum were present in some samples. The largest amounts of these phases were found in samples representative of the slip zone identified, in accordance with the macroscopic observations of the geognostic cores, which show evidence of saline and oxide precipitates.

The clay fraction in all samples is characterised by a predominance of expandable phases. Most of these consist of irregular mixed-layer illite/smectite, representing on average $66 \%$ of the entire clay fraction, up to values of about $90 \%$. The irregular mixed-layer chlorite/smectite phase is variable along the stratigraphic sequence, with some samples that show very high values, close to or above $30 \%$ of the clay fraction. Illite occurs with contents on average at about $20 \%$, ranging from 7 to $32 \%$. Kaolinite and chlorite occur in very small amounts (Table 2). 


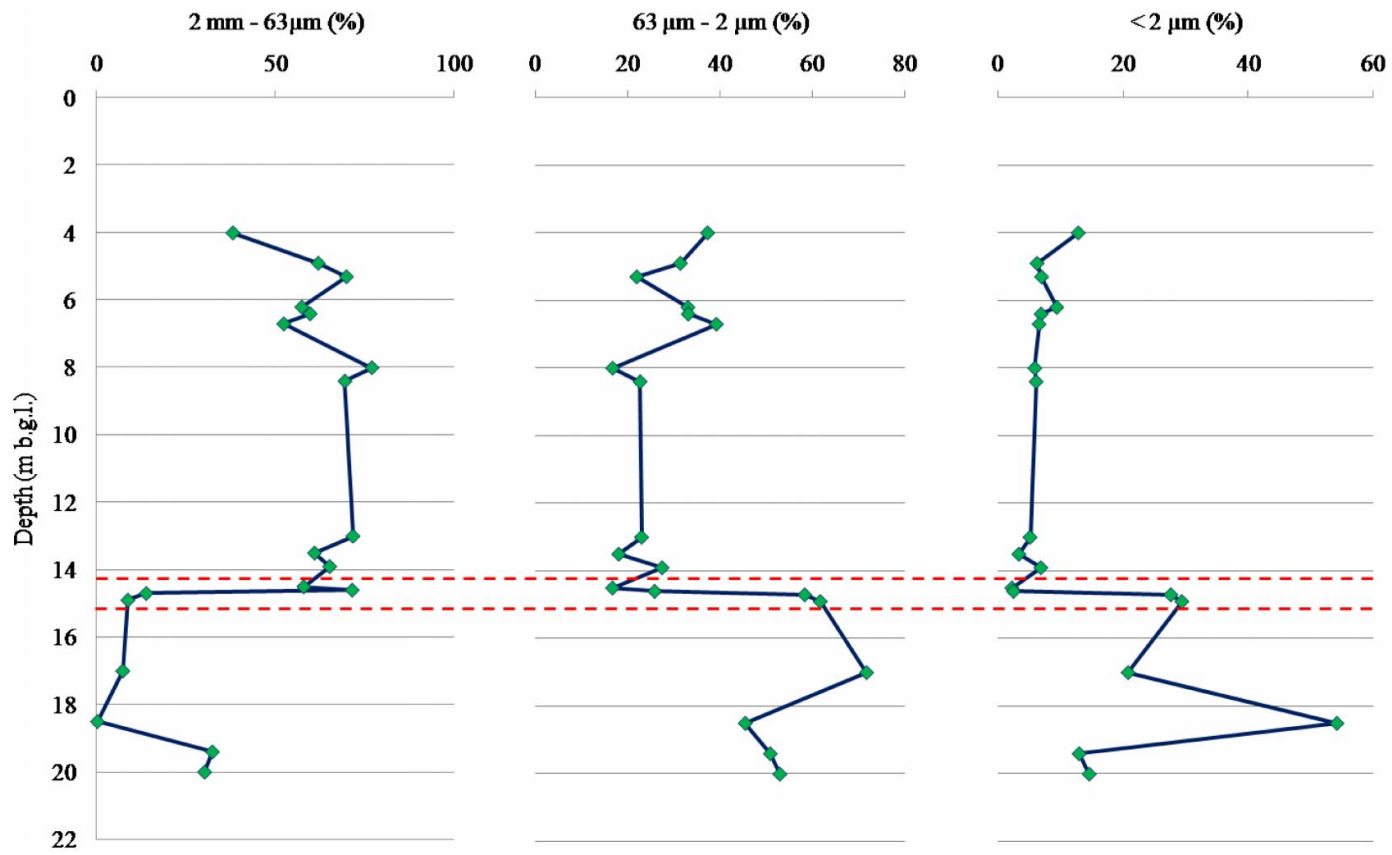

Figure 5. Trend of grain size variation with depth.

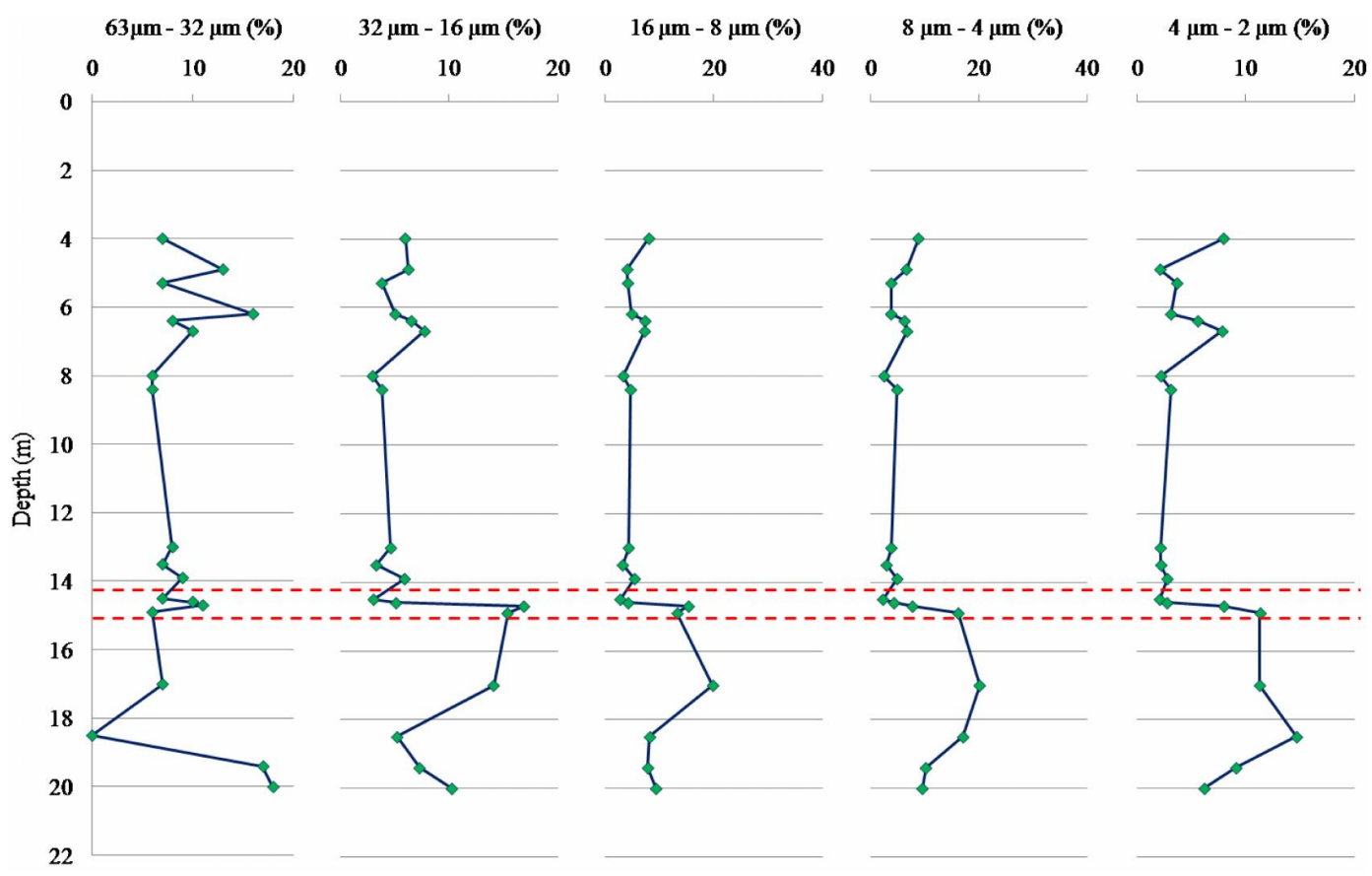

Figure 6. Trend of silt fraction variation with depth. 
Table 2. Mineralogical composition of bulk rock and clay fraction $(\mathrm{Qz}=$ quartz; Fsp = feldspar; Cal =calcite; Dol=dolomite; $\mathrm{Hem}=$ hematite $\mathrm{Gp}=$ gypsum; Chl/Sme = chlorite/smectite; Ilt/Sme = illite/smectite; Kln = kaolinite; Chl = chlorite; Ilt = illite). Slip zone samples are reported in bold.

\begin{tabular}{lcllllllllllll}
\hline Sample & Depth $(\mathrm{m})$ & \multicolumn{1}{c}{ Bulk rock $(\%)$} & \multicolumn{5}{c}{ Clay fraction $(\%)$} \\
& & Clay & Qz & Fsp & Cal & Dol & Hem & Gp & Chl/Sme & Ilt/Sme & Kln & Chl & Ilt \\
\hline C1 & 4.0 & 40 & 24 & 16 & 7 & 13 & 0 & 0 & 13 & 70 & 3 & tr & 13 \\
C2 & 4.9 & 47 & 31 & 15 & 6 & tr & 0 & tr & 20 & 43 & 5 & 0 & 32 \\
C3 & 5.3 & 32 & 39 & 23 & 5 & tr & 0 & 0 & 0 & 84 & 2 & tr & 13 \\
C4 & 6.2 & 31 & 38 & 20 & 10 & tr & 0 & 0 & 18 & 47 & 4 & tr & 30 \\
C5 & 6.4 & 45 & 31 & 16 & 8 & tr & 0 & 0 & 16 & 48 & 4 & tr & 31 \\
C6 & 6.7 & 36 & 34 & 16 & 13 & tr & 0 & 0 & 0 & 72 & 3 & tr & 25 \\
C7 & 8.0 & 18 & 61 & 18 & 3 & 0 & 0 & 0 & 35 & 41 & 3 & 2 & 20 \\
C8 & 8.4 & 32 & 44 & 19 & 5 & 0 & 0 & tr & 0 & 73 & 4 & 4 & 20 \\
C8 A & 13.0 & 21 & 46 & 19 & 10 & 3 & 2 & tr & 0 & 84 & 2 & 2 & 11 \\
C8 B & 13.5 & 18 & 49 & 22 & 6 & 2 & 2 & tr & 18 & 53 & 3 & 6 & 20 \\
C8 C & 13.9 & 22 & 39 & 25 & 10 & 2 & tr & tr & 0 & 78 & 3 & 2 & 17 \\
C9 A & $\mathbf{1 4 . 5}$ & $\mathbf{1 1}$ & $\mathbf{5 6}$ & $\mathbf{1 8}$ & $\mathbf{8}$ & $\mathbf{t r}$ & $\mathbf{5}$ & $\mathbf{t r}$ & $\mathbf{3 1}$ & $\mathbf{4 4}$ & $\mathbf{3}$ & $\mathbf{4}$ & $\mathbf{1 8}$ \\
C9 B & $\mathbf{1 4 . 6}$ & $\mathbf{2 8}$ & $\mathbf{4 1}$ & $\mathbf{1 6}$ & $\mathbf{9}$ & $\mathbf{4}$ & $\mathbf{2}$ & $\mathbf{t r}$ & $\mathbf{0}$ & $\mathbf{8 0}$ & $\mathbf{3}$ & $\mathbf{3}$ & $\mathbf{1 4}$ \\
C9 C & $\mathbf{1 4 . 7}$ & $\mathbf{5 3}$ & $\mathbf{2 8}$ & $\mathbf{1 2}$ & $\mathbf{t r}$ & $\mathbf{t r}$ & $\mathbf{2}$ & $\mathbf{2}$ & $\mathbf{0}$ & $\mathbf{7 0}$ & $\mathbf{5}$ & $\mathbf{3}$ & $\mathbf{2 2}$ \\
C9 D & $\mathbf{1 4 . 8}$ & $\mathbf{5 3}$ & $\mathbf{3 0}$ & $\mathbf{9}$ & $\mathbf{6}$ & $\mathbf{t r}$ & $\mathbf{t r}$ & $\mathbf{0}$ & & & & & \\
C9 E & $\mathbf{1 4 . 9}$ & $\mathbf{5 7}$ & $\mathbf{2 8}$ & $\mathbf{7}$ & $\mathbf{2}$ & $\mathbf{2}$ & 2 & $\mathbf{3}$ & $\mathbf{0}$ & $\mathbf{6 8}$ & $\mathbf{5}$ & $\mathbf{3}$ & $\mathbf{2 4}$ \\
C10 & 17.0 & 78 & 15 & 5 & 3 & 0 & 0 & 0 & $\mathbf{0}$ & 71 & 5 & 3 & 22 \\
C11 & 18.5 & 93 & 7 & 0 & 0 & 0 & 0 & $\operatorname{tr}$ & 0 & 74 & 3 & 3 & 20 \\
C12 & 19.4 & 53 & 32 & 13 & 2 & 0 & 0 & 0 & 25 & 64 & 3 & tr & 7 \\
C13 & 20.0 & 32 & 45 & 16 & 6 & 0 & 0 & 0 & 0 & 88 & 3 & tr & 8 \\
$\bar{\chi}$ & & 40 & 36 & 15 & 6 & 2 & 1 & 1 & 9 & 66 & 3 & 2 & 20 \\
$\sigma$ & & 21 & 13 & 6 & 3 & 3 & 1 & 1 & 12 & 15 & 1 & 1 & 7 \\
\hline
\end{tabular}

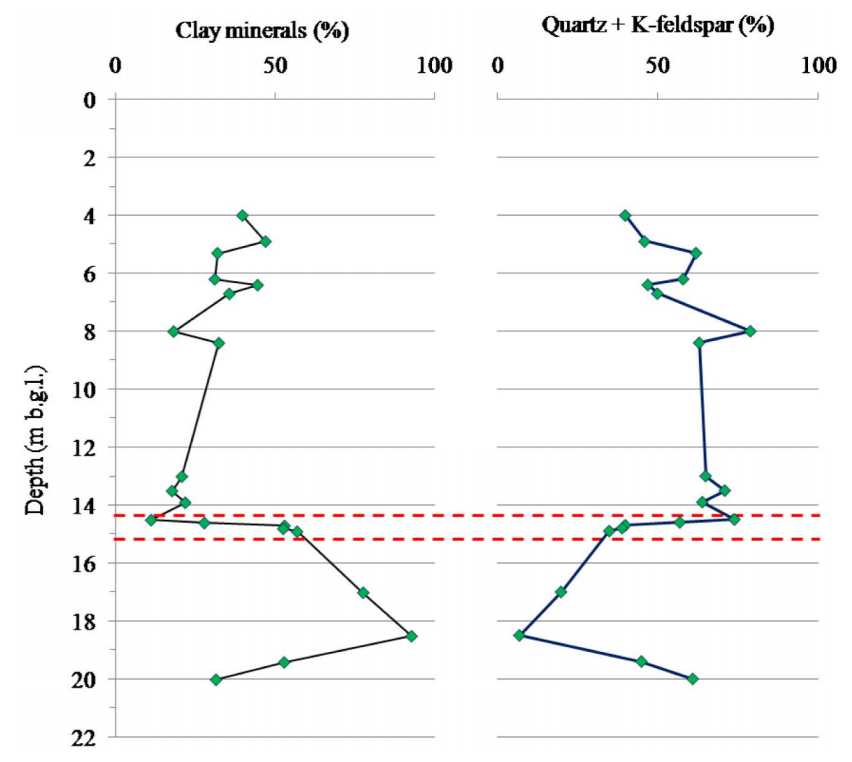

Figure 7. Trends of clay mineral content, quartz and K-feldspars with depth.

From about $14.5 \mathrm{~m}$ below ground level, clay mineral amounts increase significantly, and there is an abrupt reduction in the quartz-feldspathic component (Fig. 7).

\subsection{Geochemical and hydrogeochemical characters}

The results of the chemical analyses of the sediments are reported in Table 3.

The $\mathrm{pH}$ of all samples is mainly neutral-alkaline, with a maximum value of 8.7 , with the exception of sample C11, showing an acid character ( $\mathrm{pH}$ 5.7), probably due to large amounts of organic matter. The average quantity of the organic matter is about $30 \mathrm{~g} \mathrm{~kg}^{-1}$; however, this is variable and significantly increases below a depth of about $14.5 \mathrm{~m}$, in correspondence to the slip zone. $\mathrm{C}_{\mathrm{org}}$ and $\mathrm{N}_{\text {tot }}$ also increase at this depth (Fig. 8). The $\mathrm{C}_{\text {org }} / \mathrm{N}_{\text {tot }}$ ratio is a good indicator of the degree of decomposition and the quality of organic matter held in the soil (Batjes, 1996). The general trend of the values suggests that a low $\mathrm{C}_{\text {org }} / \mathrm{N}_{\text {tot }}$ ratio is indicative of sediments containing relatively fresh organic matter, reflecting a greater degree of humification of organic matter, as opposed to values greater than 50, where mineralisation is favoured (Waksman, 1924; Parton et al., 2007; Russell et al., 2009; Nadi et al., 2012; Fig. 9).

The sodium adsorption ratio shows a small variation at the slip zone (Fig. 10). The cation exchange capacity increases at the slip zone, decreasing progressively downward (Fig. 10). In particular, at the slip zone, exchangeable magnesium and potassium increase, whereas exchangeable calcium and sodium decrease (Fig. 11). 
Table 3. Chemical composition of analysed samples $\left(\mathrm{C}_{\text {org }}=\right.$ organic carbon; $\mathrm{N}_{\text {tot }}=$ total nitrogen; OM= organic matter; $\mathrm{C} / \mathrm{N}=\mathrm{C} / \mathrm{N}$ ratios; $\mathrm{SAR}=$ sodium adsorption ratio $; \mathrm{CEC}=$ cation exchange capacity; $\mathrm{ESP}=$ exchangeable sodium percentage $\mathrm{EPP}=$ exchangeable potassium percentage; $\mathrm{ECP}=$ exchangeable calcium percentage; $\mathrm{EMP}=$ exchangeable magnesium percentage). Slip zone samples are reported in bold.

\begin{tabular}{|c|c|c|c|c|c|c|c|c|c|c|c|c|}
\hline Sample & $\begin{array}{r}\text { Depth } \\
(\mathrm{m})\end{array}$ & $\mathrm{pH}$ & $\begin{array}{l}\mathrm{C}_{\mathrm{org}} \\
\left(\mathrm{g} \mathrm{kg}^{-1}\right)\end{array}$ & $\begin{array}{l}\mathrm{N}_{\text {tot }} \\
\left(\mathrm{g} \mathrm{kg}^{-1}\right)\end{array}$ & $\begin{array}{r}\text { OM } \\
\left(\mathrm{g} \mathrm{kg}^{-1}\right)\end{array}$ & $\mathrm{C} / \mathrm{N}$ & $\begin{array}{l}\text { SAR } \\
\left(\text { meq }^{-1}\right)\end{array}$ & $\begin{array}{l}\text { CEC } \\
\left(\text { meq } 100 g^{-1}\right)\end{array}$ & $\begin{array}{l}\text { ESP } \\
(\%)\end{array}$ & $\begin{array}{l}\text { EPP } \\
(\%)\end{array}$ & $\begin{array}{l}\mathrm{ECP} \\
(\%)\end{array}$ & $\begin{array}{l}\text { EMP } \\
(\%)\end{array}$ \\
\hline $\mathrm{C} 1$ & 4.0 & 8.5 & 1.4 & 0.3 & 2.5 & 4.7 & 2.4 & 24 & 12.1 & 2.8 & 70.0 & 15.1 \\
\hline $\mathrm{C} 2$ & 4.9 & 8.6 & 0.1 & 0.2 & 0.2 & 0.5 & 2.8 & 22 & 12.7 & 1.6 & 76.1 & 9.6 \\
\hline $\mathrm{C} 3$ & 5.3 & 8.6 & & & & & 2.6 & 22 & 12.5 & 1.8 & 75.0 & 10.7 \\
\hline $\mathrm{C} 4$ & 6.2 & 8.6 & 0.2 & 0.2 & 0.4 & 1.0 & 4.3 & 23 & 12.4 & 1.4 & 74.6 & 11.6 \\
\hline $\mathrm{C} 5$ & 6.4 & 8.7 & 0.2 & 0.3 & 0.3 & 0.7 & 1.4 & 24 & 12.4 & 1.9 & 73.1 & 12.6 \\
\hline C6 & 6.7 & 8.6 & & & & & 1.6 & 22 & 12.4 & 1.8 & 74.8 & 11.0 \\
\hline $\mathrm{C} 7$ & 8.0 & 7.8 & 3.5 & 0.1 & 6.1 & 35.0 & 1.8 & 20 & 12.3 & 1.3 & 80.3 & 6.1 \\
\hline $\mathrm{C} 8$ & 8.4 & 7.8 & 7.0 & 0.3 & 12.1 & 23.3 & 1.8 & 21 & 12.1 & 1.3 & 78.3 & 8.3 \\
\hline C8 A & 13.0 & 8.1 & 6.7 & 0.3 & 11.6 & 22.3 & 1.6 & 22 & 11.9 & 2.2 & 75.8 & 10.1 \\
\hline C8 B & 13.5 & 8.1 & 4.2 & 0.1 & 7.2 & 42.0 & 1.4 & 19 & 12.5 & 1.2 & 82.2 & 4.1 \\
\hline $\mathrm{C} 8 \mathrm{C}$ & 13.9 & 7.9 & 11.3 & 0.6 & 19.6 & 18.8 & 1.6 & 21 & 11.9 & 1.8 & 75.6 & 10.8 \\
\hline C9 A & 14.5 & 7.9 & 5.3 & 0.1 & 9.1 & 53.0 & 1.4 & 20 & 12.0 & 1.4 & 80.6 & 6.0 \\
\hline C9 B & 14.6 & 8.0 & 7.7 & 0.3 & 13.2 & 25.7 & 1.6 & 22 & 11.7 & 2.0 & 75.6 & 10.7 \\
\hline C9 C & 14.7 & 7.3 & 22.4 & 1.1 & 38.6 & 20.4 & 1.1 & 24 & 11.1 & 3.7 & 70.4 & 14.8 \\
\hline C9 D & 14.8 & 7.8 & 22.1 & 1.1 & 38 & 20.1 & 1.4 & 25 & 11.5 & 3.6 & 69.1 & 15.8 \\
\hline C9 E & 14.9 & 6.9 & 38.7 & 1.4 & 66.7 & 27.6 & 1.0 & 27 & 10.7 & 2.8 & 72.4 & 14.1 \\
\hline C10 & 17.0 & 8.1 & 7.8 & 1.0 & 13.5 & 7.8 & 1.3 & 26 & 11.5 & 4.5 & 66.3 & 17.7 \\
\hline $\mathrm{C} 11$ & 18.5 & 5.7 & 169.4 & 4.0 & 292.0 & 42.4 & 1.5 & 21 & 14.5 & 3.9 & 56.8 & 24.8 \\
\hline $\mathrm{C} 12$ & 19.4 & 8.2 & 2.2 & 0.4 & 3.9 & 5.5 & 1.4 & 20 & 13.8 & 4.6 & 65.3 & 16.3 \\
\hline $\mathrm{C} 13$ & 20.0 & 8.5 & 4.8 & 0.4 & 8.3 & 12.0 & 1.5 & 19 & 14.2 & 2.5 & 69.9 & 13.4 \\
\hline $\bar{\chi}$ & & 8.0 & 17.5 & 0.7 & 30.2 & 19.9 & 1.8 & 22 & 12.3 & 2.4 & 73.1 & 12.2 \\
\hline$\sigma$ & & 1.0 & 39.2 & 0.9 & 67.5 & 14.9 & 0.8 & 2 & 0.9 & 1.1 & 5.9 & 4.7 \\
\hline
\end{tabular}

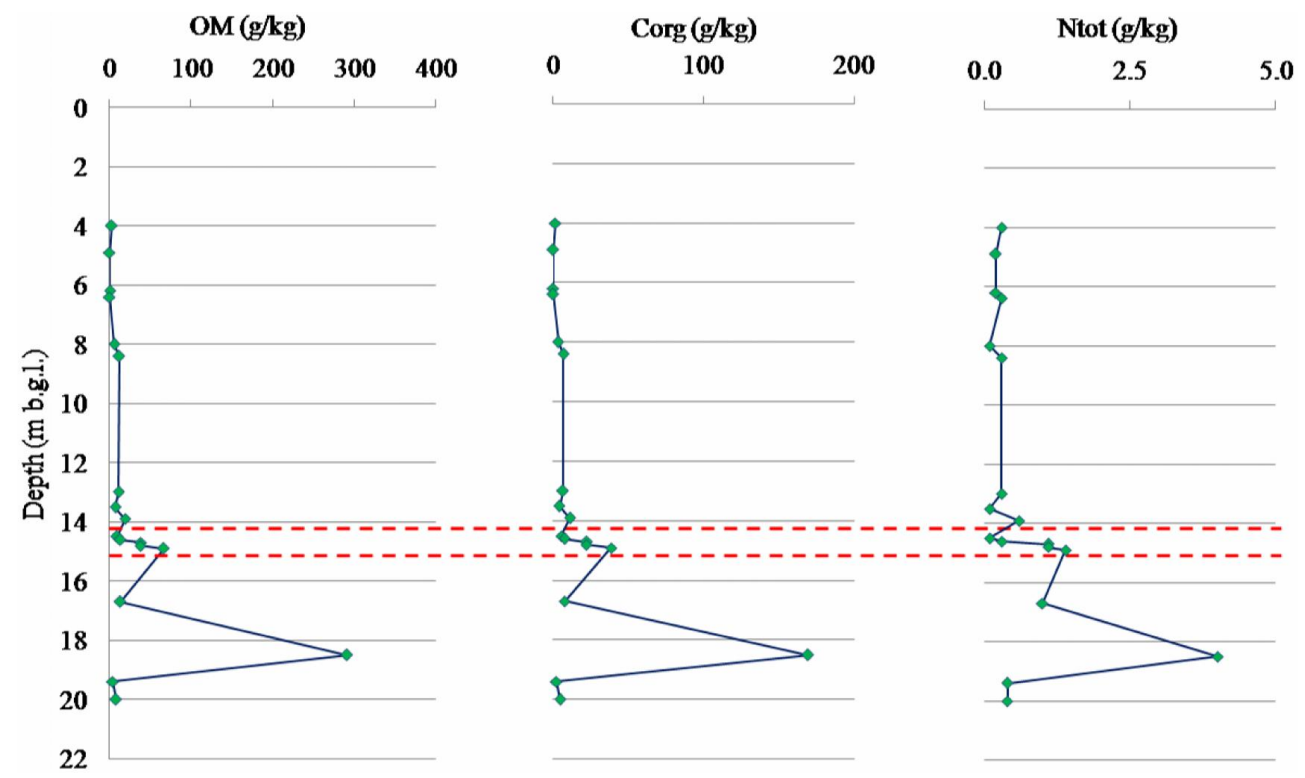

Figure 8. Trends of organic matter $(\mathrm{OM})$, organic carbon $\left(\mathrm{C}_{\mathrm{org}}\right)$ and total nitrogen $\left(\mathrm{N}_{\text {tot }}\right)$ variations with depth. 


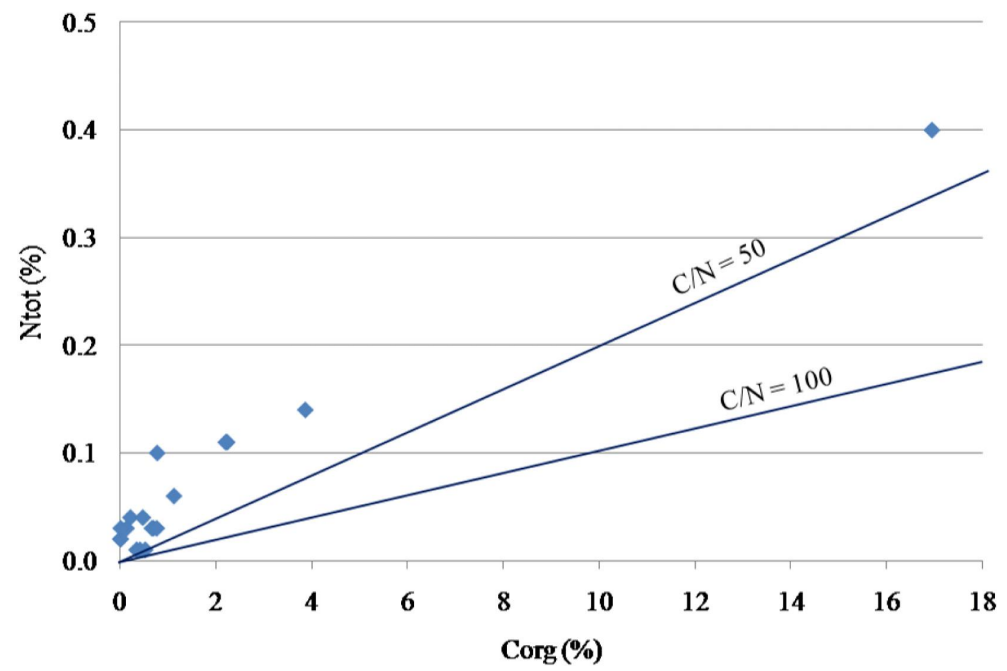

Figure 9. Total nitrogen $\left(\mathrm{N}_{\text {tot }}\right)$ vs. organic carbon $\left(\mathrm{C}_{\text {org }}\right)$ diagram.

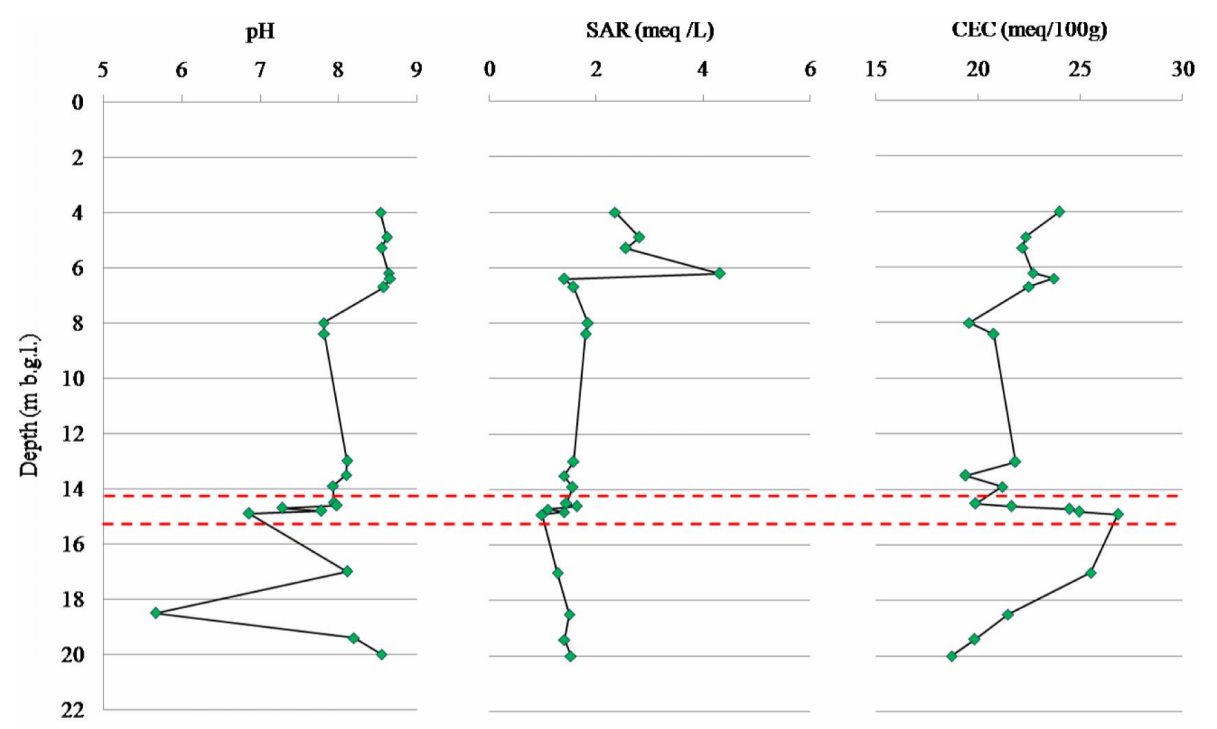

Figure 10. Trends of $\mathrm{pH}$, sodium absorption ratio (SAR) and cation exchange capacity (CEC) variations with depth.

Chemical analyses carried out of waters circulating in the sediments of the landslide allowed the classification of these waters into calcium bicarbonate facies (Fig. 12).

\subsection{Geotechnical characters}

The results of the physical-mechanical characterisation of the samples tested are reported in Table 1.

Liquid limit (from 19 to $87 \%$ ) and plastic limit (from 14 to $57 \%$ ) are variable and abruptly increase at the slip zone, below a depth of $14.7 \mathrm{~m}$ b.g.l. Plastic index is also variable, and ranges from 5 to $38 \%$.

The residual friction angle ranges from 12 to $36^{\circ}$, with the lowest value detected in sample $\mathrm{C} 10$. The residual shear strength ranges from 94 to $275 \mathrm{kPa}$. The slip zone samples
(C9A, C9D, C9E) show a progressive decrease in residual shear strength with depth. The lowest value is detected in sample C10, below the slip zone observed.

\section{Discussion and conclusions}

Statistically significant correlations between compositional characters of sediments and their physical-mechanical properties were found.

The highest values of plasticity are linked to the largest percentages of clay minerals, exchangeable magnesium and potassium (Tables 1-3). The lowest values were observed in samples also showing the highest residual friction angle. 


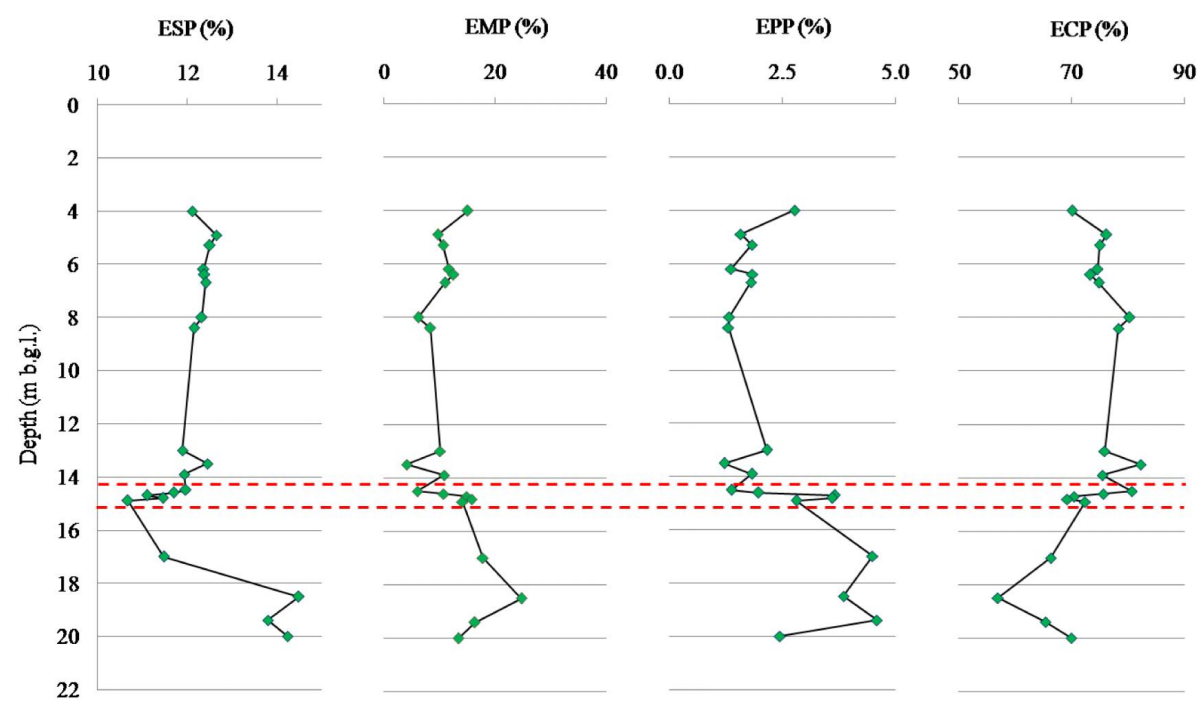

Figure 11. Trends of exchangeable sodium percentage (ESP), exchangeable magnesium percentage (EMP), exchangeable potassium percentage (EPP) and exchangeable calcium percentage (ECP) variations with depth.

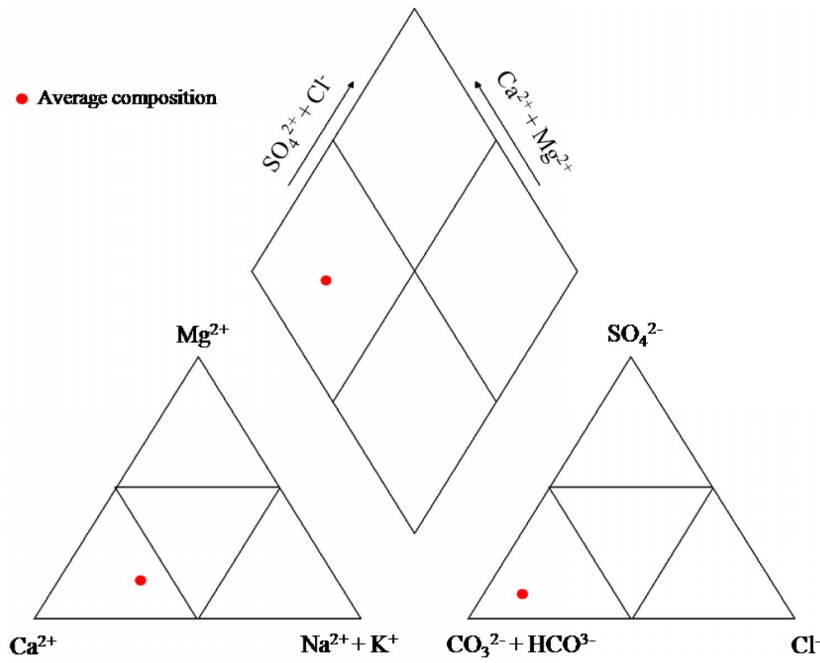

Figure 12. Piper diagram of waters circulating in the landslide.

Correlations between silty fractions and the residual friction angle were found. Particularly, the $32-2 \mu \mathrm{m}$ fraction is inversely correlated with the residual friction angle (Fig. 13c), according to the increase in this grain-size fraction in the samples from the slip zone (Fig. 6). Similarly, clay mineral content is inversely correlated with residual shear strength and the residual friction angle (Fig. 13a and b), in accordance with the increase in this phase at the slip zone (Fig. 7). Total nitrogen is also correlated negatively with residual shear strength (Fig. 13d).

An inverse relationship between residual shear strength and CEC was found, as well as between EMP, EPP and the residual friction angle. Conversely, ECP is directly related to the residual friction angle (Fig. 14). These correlations are also in accordance with the respective depth trend (Figs. 1011).

These results allow the identification of some links between the compositional characters of the sediments and the development of the slip zone. The increase in the 32-2 $\mu \mathrm{m}$ fraction at the slip zone and its negative correlation with the residual friction angle demonstrate that this grain-size fraction can be a hazard factor with respect to the development of the slip zone. The conditioning of the mineralogical composition on the mechanical behaviour of the sediments and on the development of the slip zone is also well represented by the depth trend of the clay mineral content, and by its correlation with the residual friction angle and residual shear strength. Conversely, the presence of sulfates (gypsum) and iron oxides (e.g. hematite) at the slip zone could be a result of a more significant fluid circulation, facilitating weathering of sediments and deposition of new mineral phases, as a result of ongoing oxidation and solubilisation-precipitation processes.

Organic matter, increasing at the slip zone (Fig. 8), can be considered a critical parameter with respect to the physicalmechanical behaviour of the sediments, as already suggested by other authors (Barras and Paul, 1999; Paul and Barras, 1999; Diaz-Rodriguez, 2003). The negative correlation between total nitrogen and residual shear strength allows us to hypothesise a more significant influence of this parameter, indicative of a more fresh organic matter than organic carbon. In agreement with this hypothesis, one of the lowest $\mathrm{C} / \mathrm{N}$ ratios was detected (Table 3) in sample $\mathrm{C} 10$, showing the lowest residual shear strength (Table 1).

Despite the slight variation in SAR at the slip zone, no statistically significant correlations with physical-mechanical characters were found. As a result, SAR could not be iden- 
(a)

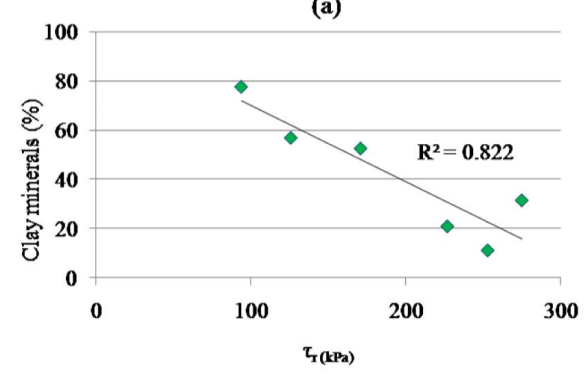

(b)

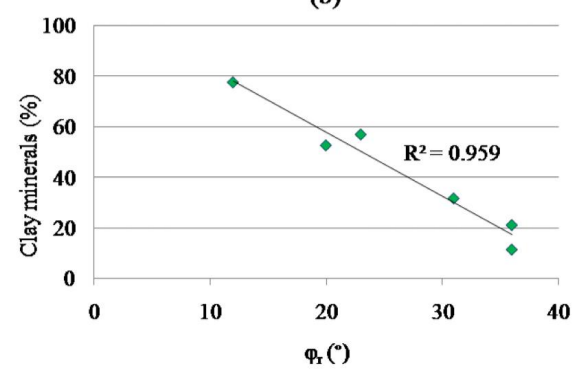

(c)

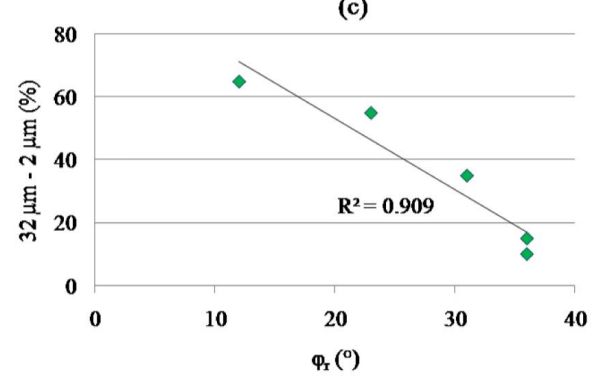

(d)

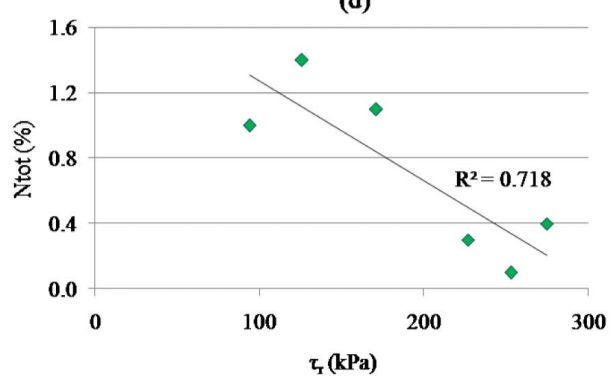

Figure 13. Correlations between residual friction angle $\left(\varphi_{\mathrm{r}}\right)$, residual shear strength $\left(\tau_{\mathrm{r}}\right)$ and some compositional characters.

(a)

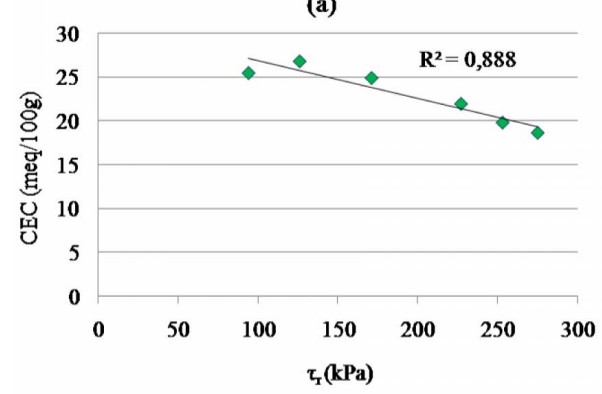

(b)

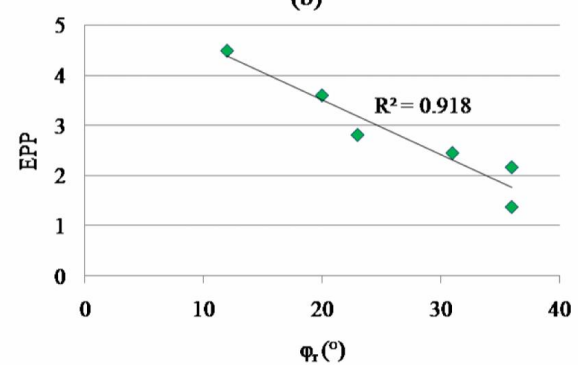

(c)

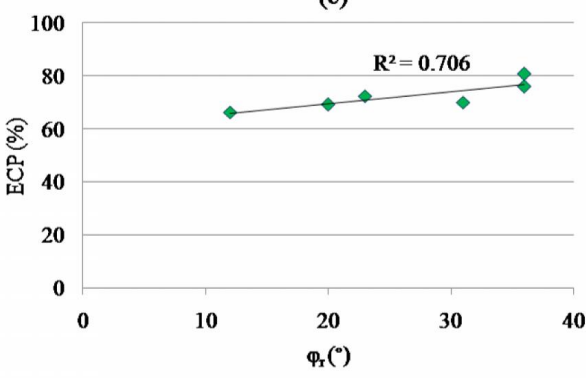

(d)

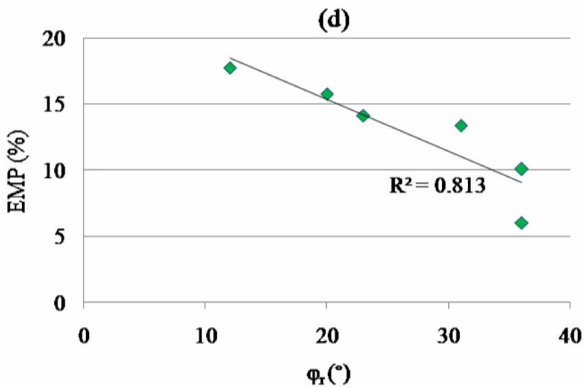

Figure 14. Correlations between some geochemical and mechanical characters $(\mathrm{CEC}=$ cation exchange capacity; $\mathrm{EPP}=$ exchangeable potassium percentage; $\mathrm{ECP}=$ exchangeable calcium percentage; $\mathrm{EMP}=$ exchangeable magnesium percentage; $\tau_{\mathrm{r}}=$ residual shear strength; $\varphi_{\mathrm{r}}=$ residual friction angle).

tified as a clear hazard factor with respect to the slip zone development. Conversely, the increase in CEC at the slip zone and its negative correlation with residual shear strength demonstrates that CEC can be considered a hazard factor with respect to the slope stability.
The lowest value of residual shear strength detected in sample C10 allows us to hypothesise a further deeper slip zone, not detectable due to the upper crack in the inclinometer tube, or a further weakness zone where it is more likely that a future slip may occur. In accordance with this hypothesis, some compositional characters recognised as hazard fac- 
tors contributing to the beginning of the movement in the slip zone (such as the $32-2 \mu \mathrm{m}$ fraction, clay mineral content and CEC) still show high values in sample C10.

This study confirms the importance of compositional characters of sediments in landslide processes, with respect to their physical-mechanical behaviour and the position of the slip zone. This demonstrates the need to carry out further specific investigations of the composition of terrain, in situ, to understand slope stability. Furthermore, it is important to understand the water-rock interaction processes in areas where landslides occur, in order to obtain further clues about the mechanisms triggering the landslides.

Acknowledgements. The authors would like to thank the Administrative Province, Potenza, which provided borehole and geognostic cores, and the Municipal Administration, Montemurro, for its logistical support.

Edited by: V. Lapenna

Reviewed by: E. Tavarnelli and three anonymous referees

\section{References}

ASTM: ASTM Book of Standards, PA, ASTM, Philadelphia, 2007.

Barras, B. F. and Paul, M. A.: Sedimentology and depositional history of the Claret Formation ("carse clay") at Bothkennar, near Grangemouth, Scot. J. Geol., 35, 131-144, 1999.

Batjes, N. H.: Total carbon and nitrogen in the soils of the world, Eur. J. Soil Sci., 47, 151-163, 1996.

Biscaye, P. E.: Mineralogy and sedimentation of recent deep-sea clay in the Atlantic Ocean and adjacent seas and oceans, Geol. Soc. Am. Bull., 76, 803-832, 1965.

Boenzi, F. and Ciaranfi, N.: Stratigrafia di dettaglio del "Flysch di Gorgoglione" (Lucania), Memorie della Società Geologica Italiana, 9, 65-79, 1970.

Boenzi, F., Ciaranfi, N., and Pieri, P.: Osservazioni geologiche nei dintorni di Accettura e di Oliveto Lucano, Memorie della Società Geologica Italiana, 7, 379-392, 1968.

Bogaard, T., Guglielmi, Y., Marc, V., Emblanch, C., Bertrand, C., and Mudry, J.: Hydrogeochemistry in landslide research: a review, B. Soc. Geol. Fr., 178, 113-126, 2007.

Bucci, F., Novellino, R., Guglielmi, P., Prosser, G., and Tavarnelli, E.: Geological map of the northeastern sector of the high Agri Valley, Southern Apennines (Basilicata, Italy), J. Maps, 8, 282292, 2012.

Bucci, F., Novellino, R., Tavarnelli, E., Prosser, G., Guzzetti, F., Cardinali, M., Gueguen, E., Guglielmi, P., and Adurno, I.: Frontal collapse during thrust propagation in mountain belts: a case study in the Lucania Apennines, Southern Italy, J. Geol. Soc. London, 171, 571-581, 2014.

Buringh, P.: Organic carbon in soils of the world, in: The Role of Terrestrial Vegetation in the Global Carbon Cycle: Measurement by Remote Sensing, edited by: Woodwell, G. M., John Wiley and Sons Ltd. Publications, New York, 91-109, 1984.

Butler, R. W. H. and Tavarnelli, E.: The structure and kinematics of substrate entrainment into high concentration sandy turbidites: a field example from the Gorgoglione "flysch" of southern Italy, Sedimentology, 53, 655-670, 2006.

Cafaro, F. and Cotecchia, F.: Structure degradation and changes in the mechanical behaviour on a stiff clay due to weathering, Géotechnique, 51, 441-453, 2001.

Cello, G.: A quantitative structural approach to the study of active fault zone in the Apennines (Peninsular Italy), J. Geodyn., 29, 265-292, 2000.

Cello, G., Gambini, R., Mattioni, L., Mazzoli, S., Read, A., Tondi, E., and Zucconi, V.: Geological analysis of the High Agri Valley (Lucanian Apennines, southern Italy), Memorie della Società Geologica Italiana, 55, 149-155, 2000a.

Cello, G., Gambini, R., Mazzoli, S., Read, A., Tondi, E., and Zucconi, V.: Fault zone characteristics and scaling properties of the Val d'Agri Fault System (southern Apennines, Italy), J. Geodyn., 29, 293-307, 2000b.

Cello, G., Tondi, E., Micarelli, L., and Mattioni, L.: Active tectonics and earthquake sources in the epicentral area of the 1857 Basilicata earthquake (southern Italy), J. Geodyn., 36, 37-50, 2003.

Chapman, H. D.: Cation exchange capacity in methods of sediment analysis - chemical and microbiological properties, Agronomy, 9, 891-901, 1965.

Cotecchia, F.: Mechanical behaviour of the stiff clays from the Montemesola Basin in relation to their geological history and structure, Charact. Eng. Proper. Nat. Sediment., 2, 817-850, 2003.

Critelli, S. and Loiacono, F.: Provenienza e dispersione dei sedimenti nel flysch di Gorgoglione (Langhiano-Tortoniano, Appennino Lucano): implicazioni sull'evoluzione delle mode detritiche arenacee nell'orogene sudappenninico, Memorie della Società Geologica Italian, 41, 809-826, 1988.

Diaz-Rodriguez, J. A.: Characterisation and engineering properties of Mexico City lacustrine soils, Charact. Eng. Proper. Nat. Sediment., 1, 725-755, 2003.

Di Maio, C.: The influence of pore fluid composition on the residual shear strength of some natural clayey sediments, in: Proceedings of 7th International Symposium on Landslides, Trondheim, Norway, 17-21, 1189-1194, 1996a.

Di Maio, C.: Exposure of bentonite to salt solution: osmotic and mechanical effects, Géotechnique, 46, 695-707, 1996b.

Di Niro, A., Giano, S. I., and Santangelo, N.: Primi dati sull'evoluzione geomorfologica e sedimentaria del bacino dell'alta Val d'Agri (Basilicata), Studi Geologici Camerti, 1992/1, 257-263, 1992.

Gueguen, E., Bentivenga, M., Colaiacovo, R., Margiotta, S., and Summa, V.: The Verdesca landslide in the Agri Valley (Basilicata, Southern Italy): a new geological and geomorphological framework, Nat. Hazards Earth Syst. Sci. Discuss., in press.

Loroueil, S. and Hight, D. W.: Behaviour and properties of natural sediments and soft rocks, Charact. Eng. Proper. Nat. Sediment., 2, 29-254, 2003.

Martinez-Nistal, A., Veniale, F., Setti, M., and Cotecchia, F.: A scanning electron microscopy image processing method for quantifying fabric orientation of clay geomaterials, Appl. Clay Sci., 14, 235-243, 1999.

Moore, D. M. and Reynolds, R. C.: X-Ray Diffraction and the Identification and Analysis of Clay Minerals, Oxford University Press, 332 pp., 1989. 
Mutti, E. and Normark, W. R.: Comparing examples of modern and ancient turbidite systems: problems and concepts, in: Marine Clastic Sedimentology, edited by: Leggett, J. K. and Zuffa, G. G., Graham-Trotman, London, 1-38, 1987.

Nadi, M., Sedaghati, E., and Fuleky, G.: Evaluation of humus quality of forest soils with two extraction methods, Int. J. Forest Soil Eros., 2, 124-127, 2012.

Parton, W., Silver, W. L., Burke, I. C., Grassens, L., Harmon, M. E., Currie, W. S., King, J. Y., Adair, E. C., Brandt, L. A., Hart, S. C., and Fasth, B.: Global-scale similarities in nitrogen release patterns during long-term decomposition, Science, 315, 361-364, 2007.

Paul, M. A. and Barras, B. F.: Role of organic material in the plasticity of Bothkennar clay, Géotechnique, 49, 529-535, 1999.

Russell, A. E., Cambardella, C. A., Laird, D. A., Jaynes, D. B., and Meek, D. W.: Nitrogen fertilizer effects on soil carbon balances in Midwestern US agricultural systems, Ecol. Appl., 19, 11021113, 2009.

Shepard, F. P.: Nomenclature based on sand-silt-clay ratios, J. Sediment. Petrol., 24, 151-158, 1954.

Sridharan, A.: Engineering behaviour of clays: influence of mineralogy, in: Proceedings of the Workshop on Chemo-Mechanical Coupling in Clays, edited by: Di Maio, C. , Hueckel, T., and Loret, B., FromNano-Scale to Engineering Applications, Maratea, Potenza, Italy, 3-28, 2001.
Summa, V., Tateo, F., Giannossi, M. L., and Bochicchio, A.: Relazione finale di progetto, Monitoraggio della frana di Costa della Gaveta del Comune di Potenza, Consiglio Nazionale delle Ricerche, Istituto di Metodologie per l'Analisi Ambientale, Tito Scalo, Potenza, Italy, 2007.

Summa, V., Tateo, F., Bochicchio, A., De Santis, F., Giannossi, M. L., Margiotta, S., and Renna, A.: Relazione finale di progetto, Monitoraggio e studio dei processi di alterazione dei terreni in frana presenti nei centri abitati di Grassano, Latronico e Tricarico, Consiglio Nazionale delle Ricerche, Istituto di Metodologie per l'Analisi Ambientale, Tito Scalo, Potenza, Italy, 2008.

Summa, V., Tateo, F., Giannossi, M. L., and Bonelli, C. G.: Influence of clay mineralogy on the stability of a landslide in Plio-Pleistocene clay sediments near Grassano (southern Italy), Catena, 80, 75-85, 2010.

Torrance, J. K.: Physical, chemical and mineralogical influences on the rheology of remoulded low-activity sensitive marine clay, Appl. Clay Sci., 14, 199-223, 1999.

Waksman, S. A.: Influence of microorganisms upon the carbonnitrogen ratio in the soil, J. Agr. Sci., 14, 555-562, 1924.

Zembo, I.: Stratigraphic architecture and quaternary evolution of the Val d'Agri intermontane basin (southern Apennines, Italy), Sediment. Geol., 223, 206-234, 2010. 